obtained from the Joint Honorary Secretaries, Ramsay Memorial Fellowships Trust, University College London, Gower Street, London, W.C.1. Completed application forms must be received not later than April 11, 1960.

Lady Tata Research Scholarships and Fellowships

THE Trustees of the Lady Tata Memorial Trust invite applications for grants, scholarships and fellowships for research on diseases of the blood, with special reference to leukremia, in the academic year beginning on October 1. In view of the affinity between leukæmia and other forms of neoplastic disease, candidates with programmes of research on any aspect of malignant disease which may throw light on problems of leukæmia will be eligible for consideration. Further information can be obtained from the Secretary of the (European) Scientific Advisory Committee, Lady Tata Memorial Trust, Chester Beatty Research Institute, Fulham Road, London, S.W.3. Applications must be submitted before March 31, 1960.

\section{Lectures at the Imperial College, London}

THE nine inaugural lectures delivered at the Imperial College of Science and Technology during 1956-57 and $1957-58$ have now been issued as a bound volume. They comprise those of Prof. B. G. Peters on "Para sitology at Imperial College"; Prof. J. G. Ball on "Metallurgy-Art, Technology, Science"; Prof. W. K. Hayman on "Pure Mathematics at a Technological University" ; Prof. Abdus Salam, "Elementary Particles" ; Prof. P. V. Danckwerts, "Chemical Engineering in a University" ; Prof. D. H. R. Barton, "Some Modern Trends in Organic Chemistry"; Prof. C. C. Butler, "Ultra-High Energy Nuclear Physics"; Prof. F. D. Richardson, "The Changing World of the Extraction Metallurgist"; and Prof. J. M. Kay on "The Nuclear Power Programme and its Impact on Engineering Education" ( $p p$. ii $+134+24$ plates. London: Imperial College of Science and Technology, 1959).

\section{University News :}

Birmingham

THE University of Birmingham and the University College of Rhodesia and Nyasaland have agreed that when a Medical School is established in the University College at Salisbury, Southern Rhodesia, this School will initially be an affiliated institution of the University of Birmingham. This will mean that, for the period of affiliation, students in the Medical School of the University College will be prepared for degrees in medicine of the University of Birmingham.

The following lecturers have been appointed: J. C. Maltbaek (chemistry); Dr. D. S. Urch (chemistry); G. C.-Y. Hu (highway and traffic engineering); Dr. C. G. Wall (chemical engineering); G. H. J. Bennett (industrial metallurgy); R. S. J. Good (mechanical engineering).

Cambridge

DR. KenNeth McQumlen, University lecturer in biochemistry, has been appointed College lecturer in biochemistry in Churchill College as from October 1961.

Durham

The University of Durham has received a grant from the University Grants Committee to enable it to place orders for nearly $£ 40,000$ worth of additional equipment for the University Computing Laboratory at 1 Kensington Terrace, Newcastle upon Tyne 2. At present, the Laboratory is equipped with a
Ferranti Pegasus electronic digital computer, and this installation is to be enlarged ky the addition of magnetic tape equipment and of a fast output punch.

London

DR. R. G. LIPSEy has been appointed to the University readership in economics tenable at the London School of Economics and Political Science. The title of reader in economics in the Unjversity of London has been conferred on Dr. K. J. Lancaster in respect of his post at the London School of Economics and Political Science.

\section{Announcements}

The Messel Medal, the senior award of the Society of Chemical Industry, which is awarded every two years in gold, will be presented to Viscount Chandos in Bristol on July 6 during the annual meeting of the Society. The Medal is awarded for meritorious distinction in science, literature, industry or public affairs.

Prof. E. J. WAyne, regius professor of practice of medicine in the University of Glasgow, has been appointed chairman of the Clinical Research Board, in succession to Sir Geoffrey Jefferson.

Dr. David K. Detweiler, associate professor of veterinary pharmacology in the University of Pennsylvania, has been awarded a grant of $1,100,000$ dollars over a period of ten years from the National Heart Institute of the National Institutes of Health, for research and training in comparative cardiovascular studies.

ThE International Society of Tropical Ecology, with its headquarters at Allahabad, India, was inaugurated by His Excellency the Governor of Bombay on January 5. The following officers were elected for 1960-61 : President, Dr. J. C. Sen Gupta (Calcutta) ; Vice-presidents, Dr. F. R. Fosberg (Washington), Dr. C. G. G. J. Van Steenis (Holland); Treasurer, Dr. R. Misra; General Secretary, Dr. G. S. Puri.

AN international symposium on "Inhaled Particles and Vapours", organized by the British Occupational Hygiene Society, will be held in Oxford during March 29-April 1. Further information can be obtained from Dr. J. S. McLintock, Medical Service, National Coal Board, Hobart House, London, S.W.1.

A SYMPosium on "Inorganic Chemistry" will be held in the Wallberg Building, Department of Chemistry, University of Toronto, on April 8. Further information can be obtained from Dr. A. D. Allen, Department of Chemistry, University of Toronto, Toronto 5.

A symposium on "Continuous Culture of Microorganisms" will be held during March 31-April 1 at University College, London, under the auspices of the Microbiology Group of the Society of Chemical Industry. Further information can be obtained from the Assistant Secretary of the Society, at 14 Belgrave Square, London, S.W.I.

IN the review of the book, "Mathematical Methods of Operations Research", by T. L. Saaty, published in Nature of December $5,1959, \mathrm{p} .1763$, it was stated that a printing error occurred on p. 340. Mr. R. Syski, of Hivac, Ltd., South Ruislip, Middlesex, has pointed out that this is not the case, and Prof. L. S. Goddard agrees, adding that the formula is repeated incorrectly on p. 346, where the exponent of $\mu / \lambda$ in the second term is given as $i+n-1$, whereas the correct exponent is $i-n+1$. 